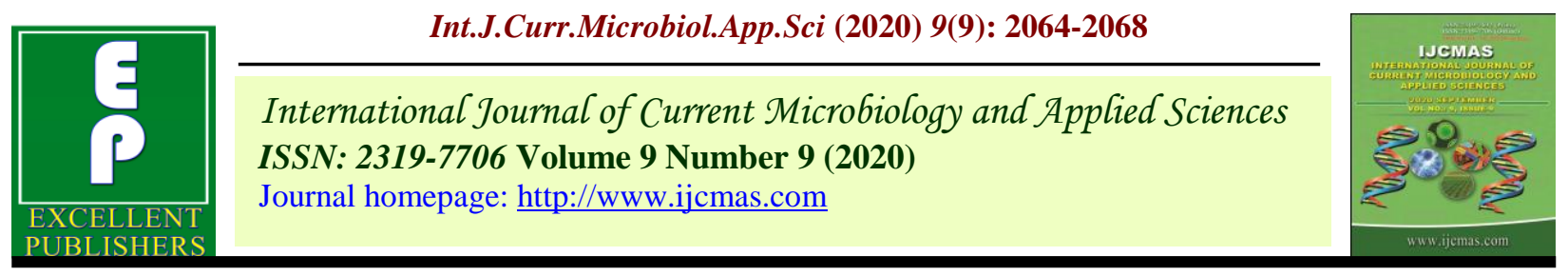

Original Research Article

https://doi.org/10.20546/ijcmas.2020.909.257

\title{
Growth and Floral Behavior of Strawberry (Fragaria $x$ ananassa Duch.) Varieties under Western Uttar Pradesh Condition
}

\author{
Sachin Kumar*, SatyaPrakash, Manoj Kumar Singh, Vipin Kumar and Arvind Kumar
}

Department of Horticulture, SVPUAT, Modipuram, Meerut-250 110 (U.P), India

*Corresponding author

\section{A B S T R A C T}

Keywords

Strawberry,

Genotypes,

Vegetative growth,

Floral characters,

Runner

Article Info

Accepted:

17 August 2020

Available Online:

10 September 2020
Strawberry (Fragaria $\times$ ananassa Duch.) varieties were evaluated to study the variability in vegetative and floral characters at the experimental farm of Sardar Vallabhbhai Patel University of Agriculture and Technology Modipuram, Meerut during 2014-2015. The experiment was laid out in Randomized Block Design (RBD) and comprised of eleven genotypes. The results showed that different strawberry cultivars exhibited marked variation in the growth and flowering characteristics. Maximum plant height was recorded in Chandler $(24.99 \mathrm{~cm})$ followed by Dana $(22.27 \mathrm{~cm})$ and plant spread in Brighton $(39.01 \mathrm{~cm})$, however, number of runners were produced maximum in Belrubi (11.38 per plant) followed by Chandler (11.28 per plant), which also recorded maximum number of leaves per plant in Douglas (15.73), leaf area in Etna $\left(121.18 \mathrm{~cm}^{2}\right)$. The date of initiation of first flowering was recorded in cultivars Gorella, Belrubi and Brighton while, the cultivar Chandler produced maximum number of flowers per runner (28.86) and duration of flowering (36 days). The study was carried out with the view to study the variability in growth characters and to find out suitable strawberry cultivar under western Uttar Pradesh condition.

\section{Introduction}

Strawberry is one of the important fruit crops of temperate region. It is also grown to a limited extent in subtropical areas. It is very much liked for its cool and refreshing nature. Fruits are of high demand for fresh market and for processing industries. It is not only consumed as fresh fruit but is also used in processed foods such as jam, ice cream, biscuits and so on. The demand for strawberry fruits for domestic as well as export markets has been increasing steadily. The other important advantage of strawberry cultivation as gives early and high returns from a unit area (Sharma and Sharma, 2004). Yield and fruit quality of strawberry is influenced by a number of factors like growing environment, soil condition and cultivars. Considerable variation occurs in the adoption of various strawberry cultivars (Joolka and Badiyala, 1983). The research work for finding suitable 
varieties has however, been limited under sub-tropical region of Western Uttar Pradesh condition. Therefore, the present investigation was planned with the objective to assess the performance of eleven different cultivars in Western Uttar Pradesh.

\section{Materials and Methods}

The plant material comprises of eleven varieties of strawberry were procured from IARI, Regional Station, Shimla (HP). Healthy and uniform runners were transplanted in the experimental field of Department of Horticulture, SVPUA \& T, Modipuram, Meerut in second fortnight of November, 2014. The experiment was laid out in a randomized block design with three replications. From each variety and in each replication sixteen runners were planted in raised beds of $1.20 \times 1.20 \mathrm{~m}$ area with spacing of $30 \times 30 \mathrm{~cm}$. Applications of manures and fertilizers, irrigation, intercultural operations and plant protection measures were taken as per need and recommended package. The observations on growth and floral characters were recorded on five randomly chosen plants per replication. Plant height, plant spread and runner length was measured with the help of measuring scale and expressed in $\mathrm{cm}$, whereas leaf area was measured on leaf area meter. The data thus obtained were analyzed following standard procedure (Panse and Sukhatme, 1989).

\section{Results and Discussion}

The results of the present investigation clearly indicate that all the strawberry varieties exhibited significant variation with respect to plant height, plant spread, number of leaves per plant, leaf area, number of runners per plant and runner length (Table 1). Plant height ranged from 18.90 to $24.99 \mathrm{~cm}$ in different varieties with maximum in chandler (24.99 $\mathrm{cm})$ followed by variety Dana $(22.27 \mathrm{~cm})$ and minimum in Etna $(18.90 \mathrm{~cm})$. Plant spread ranged from 31.21 to $39.01 \mathrm{~cm}$ in different varieties. Maximum plant spread was observed in cultivar Brighton (39.01 cm) followed by Chandler $(34.83 \mathrm{~cm})$ and Selva $(34.17 \mathrm{~cm})$. Lowest plant spread was recorded in cultivar Pajaro $(31.21 \mathrm{~cm})$. Plant height and spread provide an idea of the vigour of the plant and also provide information on surface available for fruit production (Kumar et al., 2016 and Rani and Ahmad, 2012). Variation differences in plant height and spread among strawberry varieties have also been reported by Das et al., (2015), Kumar and Kumar (2011), Dolgun (2006), Rao and Lal (2010), Singh et al., (2008) and Das et al., (2007).

Highest mean number of leaves per plant was observed in varieties Dana (16.66), Douglas (15.73) and Brighton (15.66). Lowest numbers of leaves were recorded in cultivar Pajaro (10.93). Maximum leaf area of 121.18 $\mathrm{cm}^{2}$ was observed in cultivar Etna followed by Gorella $\left(114.96 \mathrm{~cm}^{2}\right)$. Least leaf area was recorded in cultivar Pajaro $\left(82.37 \mathrm{~cm}^{2}\right)$ followed by Belrubi $\left(87.38 \mathrm{~cm}^{2}\right)$. Variation in leaf area and number of leaves per plant may be attributed to genetic make up of these varieties as has also been reported by Kumar et al., (2016), Kumar and Kumar (2011) and Ram et al., (2008).

Runners are the only means of propagation in strawberries. Mean number of runners recorded among the varieties varied significantly and ranged between 7.59 to 11.38 runners per plant. Maximum number of runners per plant was observed in cultivar Belrubi (11.38) which was statistically at par with Chandler (11.28), Dana (10.78) and Gorella (10.60) followed by Etna (10.20). Least number of runners per plant was observed in cultivar Confutura (7.59) followed by Selva (7.64). However maximum length of runners was observed in cultivar Chandler $(75.24 \mathrm{~cm})$ which was statistically at 
par with Confutura $(73.51 \mathrm{~cm})$ followed by Brighton $(70.21 \mathrm{~cm})$. Lowest length of runner was observed in cultivar Pajaro $(55.09 \mathrm{~cm})$. This variation in runner number and length in strawberry varieties have been observed under sub-tropical agro-climatic conditions. The variation in runner production may be attributed to varied response of varieties to photoperiod and chilling requirement and the results are inconformity with the findings of Kumar and Kumar (2011), Das et al., (2007), Kumar et al., (2011), Moshiur et al., (2013) and Ahmad et al., (2018).

Initiation of first flowering, time of full bloom, number of flowers per runner and duration of flowering was different in the studied varieties (Table 2). Initiation of first flower occurred earliest in cultivar Gorella, Belrubi and Brighton (18 January) followed by cultivar Douglas, Selva, Confutura, Etna, Pajaro and Dana (20 January). Cultivar Chandler was the last to start flower initiation
(23 January). Cultivar Gorella was the earliest to attain time of full bloom (10 February) however cultivar Chandler was last to attain time of full bloom (25 February). In rest of the varieties the gap of full bloom was quite narrow. Maximum number of flowering per runner was recorded in cultivar Chandler (28.86). Least number of flower per runner was recorded in cultivar Etna (19.91) followed by Dana (21.70). Significant variation among the varieties was observed for duration of flowering. Cultivar Chandler was reported the maximum duration of flowering (36 days), while Gorella and Sea Scape reported the minimum duration of flowering (31.33 days). The results obtained are in conformity with the finding of Das et al., (2007), Gupta and Tripathi (2012), Das et al., (2015) and Ahmad et al., (2018) who reported that flowering in strawberry depends on day length and as temperature required by a particular cultivar.

Table.1 Growth characters of different strawberry cultivars

\begin{tabular}{|l|c|c|c|c|c|c|}
\hline Varieties & $\begin{array}{c}\text { Plant } \\
\text { height }\end{array}$ & $\begin{array}{c}\text { Plant } \\
\text { spread }\end{array}$ & $\begin{array}{c}\text { Number of } \\
\text { leaves/plant }\end{array}$ & $\begin{array}{c}\text { Leaf } \\
\text { area }\end{array}$ & $\begin{array}{c}\text { Number of } \\
\text { runners/plant }\end{array}$ & $\begin{array}{c}\text { Runner } \\
\text { length } \\
\text { (cm) }\end{array}$ \\
\hline Chandler & 24.99 & 34.83 & 14.86 & 92.38 & 11.28 & 75.24 \\
\hline Douglas & 19.67 & 33.07 & 15.73 & 98.07 & 8.85 & 63.07 \\
\hline Selva & 20.15 & 34.17 & 14.46 & 91.27 & 7.64 & 67.05 \\
\hline Confutura & 21.88 & 33.24 & 14.53 & 105.74 & 7.59 & 73.51 \\
\hline Gorella & 21.23 & 31.84 & 13.40 & 114.96 & 10.60 & 66.06 \\
\hline Etna & 18.90 & 32.25 & 13.00 & 121.18 & 10.20 & 59.11 \\
\hline Belrubi & 21.55 & 32.21 & 14.53 & 87.38 & 11.38 & 68.54 \\
\hline Brighton & 19.48 & 39.01 & 15.66 & 93.77 & 8.84 & 70.21 \\
\hline Sea Scape & 20.09 & 32.58 & 13.66 & 91.75 & 9.24 & 69.54 \\
\hline Pajaro & 19.73 & 31.21 & 10.93 & 82.37 & 8.52 & 55.09 \\
\hline Dana & 22.27 & 31.88 & 16.66 & 94.44 & 10.78 & 60.94 \\
\hline Mean & $\mathbf{2 0 . 9 0}$ & $\mathbf{3 3 . 3 0}$ & $\mathbf{1 4 . 3 1}$ & $\mathbf{9 7 . 5 7}$ & $\mathbf{9 . 5 4}$ & $\mathbf{6 6 . 2 1}$ \\
\hline CD & $\mathbf{1 . 0 9}$ & $\mathbf{2 . 3 0}$ & $\mathbf{0 . 7 8}$ & $\mathbf{1 . 7 0}$ & $\mathbf{1 . 0 6}$ & $\mathbf{2 . 0 4}$ \\
\hline & & & & & & \\
\hline
\end{tabular}


Table.2 Floral characters of different strawberry cultivars

\begin{tabular}{|l|c|c|c|c|}
\hline Varieties & $\begin{array}{c}\text { Date of } \\
\text { initiation of } \\
\text { first flowering }\end{array}$ & $\begin{array}{c}\text { Time of full } \\
\text { bloom }\end{array}$ & $\begin{array}{c}\text { Number of } \\
\text { flowers/ } \\
\text { runner }\end{array}$ & $\begin{array}{c}\text { Duration of } \\
\text { flowering (days) }\end{array}$ \\
\hline Chandler & $23 / 01 / 2015$ & $25 / 02 / 2015$ & 28.86 & 36.00 \\
\hline Douglas & $20 / 01 / 2015$ & $17 / 02 / 2015$ & 24.99 & 32.66 \\
\hline Selva & $20 / 01 / 2015$ & $18 / 02 / 2015$ & 22.78 & 33.00 \\
\hline Confutura & $20 / 01 / 2015$ & $21 / 02 / 2015$ & 23.64 & 34.33 \\
\hline Gorella & $18 / 01 / 2015$ & $10 / 02 / 2015$ & 24.18 & 31.33 \\
\hline Etna & $20 / 01 / 2015$ & $12 / 02 / 2015$ & 19.91 & 31.67 \\
\hline Belrubi & $18 / 01 / 2015$ & $18 / 02 / 2015$ & 23.83 & 34.33 \\
\hline Brighton & $18 / 01 / 2015$ & $14 / 02 / 2015$ & 22.84 & 32.33 \\
\hline Sea Scape & $22 / 01 / 2015$ & $16 / 02 / 2015$ & 25.09 & 31.33 \\
\hline Pajaro & $20 / 01 / 2015$ & $17 / 02 / 2015$ & 24.40 & 33.33 \\
\hline Dana & $20 / 01 / 2015$ & $17 / 02 / 2015$ & 21.70 & 32.33 \\
\hline Mean & & & $\mathbf{2 3 . 8 0}$ & $\mathbf{3 2 . 9 9}$ \\
\hline CD & & & $\mathbf{1 . 2 7}$ & $\mathbf{2 . 5 0}$ \\
\hline
\end{tabular}

In conclusion, most of strawberry varieties perform well in western Uttar Pradesh conditions of performance of vegetative and floral character were at par with it main growing region viz. temperate region. Strawberry cultivars exhibited marked variation. 'Chandler' was regular and performed better for other characters like plant height, flower duration, number of flower per runner. On the basis of performance and diverse nature of different varieties of strawberry in plains western Uttar Pradesh it may be conclude that the crop may be adopted for commercial cultivation in this region and it may be helpful crop diversification as well as crop improvement.

\section{References}

Ahmad M, FA Banday, MYBhat, MKSharma, MADar, A Khalil and N Nazir (2018) Performance of exotic strawberry varieties under temperate conditions of North-Western Himalayas. Indian $J$. Hort. 75(4): 698-702.

Das AK, KP Singh, B Prasad and R Kumar,
(2015) Evaluation of cultivars of strawberry, a temperate fruit for its adaptability as well as productivity in subtropical agro-climatic condition of Supaul district in Bihar. Asian J. Hor. 10(2): 278-281.

Das B, V Nath, BR Jana, P Dey, KK Pramanick and DK Kishor (2007) Performance of strawberry cultivars grown on different mulching materials under sub-humid subtropical plateau conditions of Eastern India. Indian Journal of Horticulture. 62(2): 136-143.

Dolgun O (2006) Yield performance of strawberry plug plants in Eastern Mediterranean climatic conditions. Inter. J. Agric. Res. 1(3): 280-285.

Gupta, AK and VK Tripathi (2012) Efficacy of Azotobacter and vermi-compost alone and in combination on vegetative growth, flowering and yield of strawberry (Fragaria $\mathrm{x}$ ananassa Duch.) cv. Chandler. Prog. Hort. 44(2): 256-261.

Joolka, NK and SD Badiyala (1983) Studies on the comparative performance of 
strawberry cultivars. Haryana Journal Horticultural Science. 12(3-4): 173177.

Kumar A and P Kumar(2011) Studies on vegetative growth, yield and quality attributes of strawberry under temperate agro-climatic zone conditions of Kashmir valley. Haryana J. hortic. Sci. 40(1 \& 2): 10-12.

Kumar A, RK Arasthe, B Panday, K Ramesh, R Denzanpa and H Rahmavi (2011) Varietal screening of strawberry (Fragaria $\times$ ananassa Duch.) under organic production system for fruit quality and yield in mid-hills of Sikkim, Himalayas. Indian J. Genet. Resour. 24: 243-45.

Kumar J, D Thakur, M Thakur and Babita (2016) Performance of strawberry cultivars in mid hill region of Kullu valley of Himachal Pradesh. Journal of Applied and Natural Science. 8(2): 967 $-970$.

Moshiur RM, RM Mizanur, HMMofazzal MMA Khaleque and KA Abdul (2013) Characterization and field performance of 15 strawberry germplasm under
Bangladesh conditions. SAARC J. Agric. 11: 81-94.

Panse VG and PV Sukhatme (1989) Statistical Methods for Agricultural Workers. ICAR, New Delhi.

Ram RB, SK Chaturvedi, DH Dwivedi and M Divya (2008) Evaluation of some cultivars of strawberry in sodic soil conditions. Ind. J. Hortic. 65(3): 338340.

Rani R and F Ahmad (2012) Strawberry kikheti: New source of income, Udhayanprasikchak, BAU, Sabour, pp. 104-106.

Rao VK and B Lal (2010) Evaluation of promising strawberry genotypes under Garwal Himalayan conditions. Indian Journal of Horticulture 67(4): 470-474.

Sharma VP and RR Sharma (2004) The strawberry. ICAR, New Delhi, India.

Singh A, RK Patel, LC De and LS Periera (2008) Performance of strawberry cultivars under sub-tropics of Meghalaya. Indian J. Agric. Sci., 78 (7): $1-4$.

\section{How to cite this article:}

Sachin Kumar, SatyaPrakash, Manoj Kumar Singh, Vipin Kumar and Arvind Kumar. 2020. Growth and Floral Behavior of Strawberry (Fragaria $x$ ananassa Duch.) Varieties under Western Uttar Pradesh Condition. Int.J.Curr.Microbiol.App.Sci. 9(09): 2064-2068. doi: https://doi.org/10.20546/ijcmas.2020.909.257 